\title{
THE RELATIONSHIP BETWEEN EXCISE TAXES REVENUES AND BUDGET DEFICITS IN OECD COUNTRIES: 1999-2016
}

\author{
Serdar ÖZTÜRK $\quad$ Alper Aykut EKINCi²
}

\begin{abstract}
The aim of this study is to examine the relationship between budget deficits and excise taxes revenues in OECD countries for 1999-2016 period. In the study, the bootstrap panel causality technique proposed by Kónya (2006), which considers cross-sectional dependence and heterogeneity across the countries was performed for 32 OECD member countries (Chile, Japan, Lithuania and Mexico are not included due to lack of data) yearly data of the 1999-2016 period. According to the results of the bootstrap panel causality, a significant relationship between excise tax revenue and budget deficit in OECD member countries exists. Governments due to its ease of application and general acceptance prefer excise taxes. Thus, the results can be interpreted that excise taxes are used as a revenue-increasing resource to decrease the budget deficit or to prevent increase in the budget deficit.
\end{abstract}

Key Words: Excise Tax, Budget Deficit, Causality

Jel Classification Codes: H2O, H23, H6O, H62

\section{OECD ÜLKELERINDE ÖZEL TÜKETIM VERGISi GELIRLERI VE BÜTÇE AÇIKLARI ARASINDAKI iLIŞKi: 1999-2016}

Öz

Bu çalışmanın amacı, 1999-2016 yılları için OECD ülkelerinde bütçe açıkları ile özel tüketim vergisi gelirleri arasındaki ilişkiyi incelemektir. Çalışmada, 1999-2016 dönemine ait yıllık verilerle 32 OECD üyesi ülke (Şili, Japonya, Litvanya ve Meksika veri eksikliğine dâhil edilmemiştir) için Bootstrap Panel Granger nedensellik analizi yapılmıştır. Analiz sonuçlarına göre, OECD üyesi ülkelerde bütçe açıkları ve özel tüketim vergisi gelirleri arasında Granger nedensellik ilişkisi olduğu ortaya koyulmuştur. Özel tüketim vergisi uygulamaları, uygulama kolaylığı ve genel kabulü nedeniyle hükümetler tarafından tercih edilmektedir. Dolayısıyla, sonuçlar, özel tüketim vergilerinin bütçe açığını azaltmak veya bütçe açığındaki artışı önlemek için gelir artırıcı bir kaynak olarak kullanıldığı şeklinde yorumlanabilmektedir.

Anahtar Kelimeler: Özel Tüketim Vergisi, Bütçe Açığı, Nedensellik Jel Sınıflandırma Kodları: H2O, H23, H6O, H62

\footnotetext{
1 Prof. Dr., Nevsehir Haci Bektas Veli University, Faculty of Economics and Administrative Science, Economics Department, serdarozturk@nevsehir.edu.tr, ORCID:0000-0003-0650-0244

${ }^{2}$ Research Assistant, Nevsehir Haci Bektas Veli University, Faculty of Economics and Administrative Science, Economics Department, alperekinci@nevsehir.edu.tr, ORCID: 0000-0002-3141-3380
} 


\section{Introduction}

Tax revenues that are more important than the Central Bank sources and borrowing in ensuring the budget balance have been discussed in the economic and financial literature for many years. The idea of keeping the taxes at a minimum level is replaced by the necessity of collecting more taxes over time. In the post-1980 economies of globalization, liberalization and financialization tax revenues have an important position in today's economies. Economic policies such as growth, development and social development need better preparation and implementation of budgets. Especially after the 1929 World Economic Crisis, radical changes in economic and financial thought made the budget more important. Taxes are the most important income that can be used to finance budget deficits in the financing of the budget, as well as a real source of financing for a stable development. If there is not enough tax revenue to finance public expenditures, budget deficits are unavoidable (Tüğen and Güngör, 2013: 20). In this context, excise tax is an important part of tax revenues.

Some financiers regard the excise tax as a "partial expenditure tax "on the determined goods. Therefore, it can be mentioned that the excise taxes have the effects of deflecting prices. Excises are called as "Sin Taxes" in the literature because they are applied to goods that are considered harmful such as cigarettes and alcohol. On the other hand, it is called as "Corrective Taxes" because it is applied to reduce the effects of negative externalities caused by oil and its derivatives (Altınok, 2007).

Excise taxes have practiced for centuries and commonly are used by governments today. Although, spread of income taxation and value-added taxation has reduced the importance of excise taxation as a source of government revenue, most governments still collect sizable taxes on petroleum products, tobacco products, and alcohol. Today, the share of private tax in developing countries' tax revenues is higher than in developed countries. In all OECD countries, alcoholic beverages, fuel products and tobacco products are subject to special consumption tax. However, there are differences between the member countries in the implementation of the tax, especially the tax rates. OECD, whose excise tax revenue in 2016 averaged 7,7 \% of total revenue. In the same year, this ratio for Turkey was 18,2\% while for USA 3,2\%.

\section{Purposes and Characteristics of Excise Tax}

Although the excise tax has many aims, its main purpose is to reduce the consumption of some goods that are harmful to health and environment. While it is stated that the main target of the general consumption taxes is to collect income, it is a known fact that the special consumption taxes have targets such as limiting the consumption of the goods which are thought to be harmful to the society in terms of social environment or that they are not beneficial (Mutlu, 2002:47).

In terms of economic theory, the underlying cause of taxes on products such as alcohol, tobacco, oil and certain food products is negative externalities of consumption. The negative externalities are costs that neither the producer nor the consumer pays for in the market prices (Vigo and Lauer ,2017.) If the activities carried out by an economic unit adversely affect another economic unit, it is called negative externality. Social costs created by products with negative externality negatively affect the economies of states. For this reason, governments are trying to minimize the use of products with negative externalities and the resulting social costs (Kargı and Yüksel, 2010:183-202). Arthur Cecil Pigou is the first person to suggest that taxes can be used to drop negative effects caused by negative externality products and to change consumption preferences. These taxes are also known as "Pigouvian taxes." Pigou remarked that alcohol producers are profiting by sales, but they don't have to pay the external costs related with heavy drinks such as police, health services 
and prisons. Therefore, he claimed that the alcohol tax could hamper excessive consumption of alcohol, but more importantly, that drinking alcohol increased public funds to deal with external costs (Pigou, 1920). Adam Smith in the Wealth of Nations mentions the tax on tobacco, alcohol and sugar as "Sugar, rum, and tobacco, are commodities which are nowhere necessaries of life, [but] which are ... objects of almost universal consumption, and which are therefore extremely proper subjects of taxation" (Smith,1776).

Theoretically, there are two ways of reducing the consumption of a good or service. The first of these is to prohibit the use or sale by law. However, for this to be possible, most consumers should be reluctant to consume the relevant product, and this is a very low probability. The second way to cut consumption is to intervene in the market process by using the tax system. In this way, there will be no reaction caused by the prohibition of consumption completely, as well as those who want to consume the product will be folded to the price (Buchanan, 1970: 486-492). In this sense, the excise duty has a" regulating "characteristic. For example, increasing the excise tax on alcohol and cigarettes will help to reduce the consumption of these products that are harmful to health. Similarly, the purpose of taxing on fuel is to protect natural resources and the environment (Edizdoğan and Çelikkaya, 2010). The fiscal, social, economic and political goals of excise tax may be considered separately.

\subsection{Fiscal Aims}

In addition to public services such as defense, security, education, justice and health, there is a need for a budget for technological, economic and social development. This means that taxes, which are the source of financing, are extremely important for states. The small amount of goods and liabilities that are included in the subject of excise taxes eases tax collection and provides a high amount of income to the treasury (Taylar, 2010:435-467).

As can be seen in Graph-1, OECD members' average excise tax revenues, which were \$21.4 million in 1999, increased by $46.7 \%$ and reached 31.4 million dollars in 2016 . Simultaneously in Turkey, excise tax revenue that was 25.8 million dollars in 2006 has increased by $54.2 \%$ within 10 years and reached 39.8 million dollars in 2016.

\section{Graph 1: Excise Revenue as US Dollar in Developed Countries and Turkey}

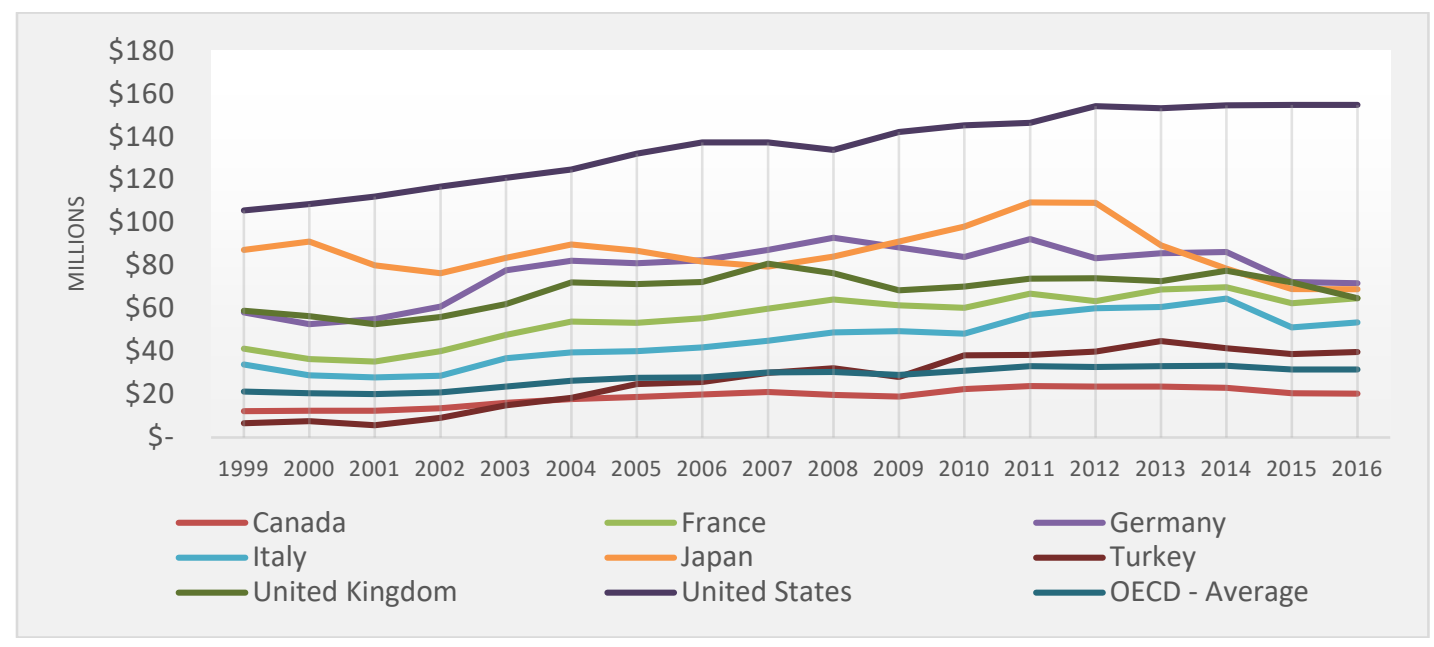

Source: Revenue Statistics - OECD countries 


\section{Graph 2: Excise Revenue as US Dollar in Turkey}

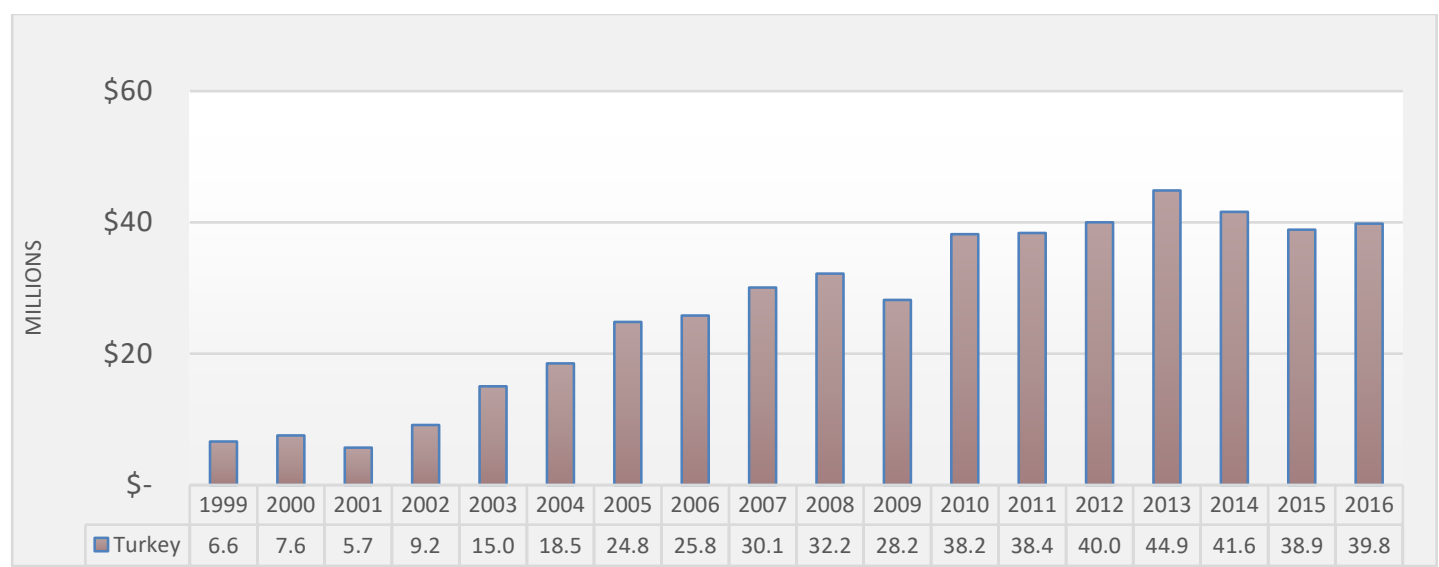

Source: Revenue Statistics - OECD countries

This increase in tax revenues can be attributed to many factors such as increasing tax rates, tax audits, and tax awareness.

\subsection{Social Aims}

Taxes are used to not only collect revenue but also sustain multiple policies such as income justice, economic development and public health. Excises on products related to public health, such as alcohol and cigarettes are good examples of the role of tax outside income generation. While such taxes have for a long time been in most countries, they continue to bring up debates about the effective designs and successful implementations of tax systems. In terms of efficiency and equality, it needs to evaluate the management skills, economic conditions and political environments of countries together and closely (Bird, 2015: 3).

In the context of public health policy, taxation mainly aims to reduce harmful products and minimize worse consequences of consumption decisions on individual and society. As Crooks defines related to alcohol taxes, is "... to restrict the damage created by alcohol consumption, by reducing (at least stopping rising) the overall average consumption per person." (Crooks, 1989: 3132).

High and verified social costs related to alcohol and tobacco consumption has been reviewed many times to weaken health argument of excise taxes on these products. The possible bad consequences of smoking and excessive alcohol consumption have been investigated by many disciplines. In both developed and developing countries, the economic, psychosocial and medical aspects of these damages have been investigated and possible traffic accidents, labor losses and familial problems have been estimated.

Smoking and excessive alcohol consumption cause harm to those who consume them firstly and thus threaten the public health. At the same time, result due to the damage to social welfare a tax to reduce consumption will clearly be considered as a better (Bird,2015: 22).

\subsection{Economic and Political Aims}

Taxes are one of the tools of state intervention to the economy and play an active role in achieving economic targets (Eker, 1998). 
Excise taxes can also be used to bring indirect taxes to a progressive and thus to reduce inequalities in the distribution of taxes. In cases where a progressive income tax is difficult to implement, excise taxes on luxury goods can be used as a means of regulating income distribution, especially in underdeveloped countries (Taylar, 2010:435-467).

The economic approach examines the social costs of alcohol and tobacco in a narrower sense and focuses on externalities that are applied to society in general rather than total social costs.

Other important reasons of excises on tobacco and alcohol are negative images related with consumption of tobacco and alcohol. These undesirable reputations of tobacco and alcohol consumptions make public to accept such excise son them easier than income or sales taxes. Most people consider that alcohol and tobacco consumption because social costs to justify relatively heavy taxation on them. Thus, Tobacco and alcohol-related taxes are always attractive to policymakers, as relatively acceptable way of mobilizing revenues (Brezis and Marans, 2010).

\section{Excise Tax Revenue in OECD Countries}

The proportion of the excise tax in GDP varies considerably in OECD member countries. This ratio is $1,2 \%$ in Switzerland and $0,8 \%$ in U.S.A. On the other hand, while the average of the OECD is $2,6 \%$, in Turkey this ratio is $4,6 \%$. In addition, Turkey is the OECD member which excises have the highest proportion in GDP (Revenue Statistics - Oecd countries: Comparative tables, 2016).

In most OECD member countries, the ratio of excise taxes to GDP declined in the period 20002016. While OECD average of excises revenue-GDP ratio she was $2.9 \%$ in 2000 , it has declined to $2.6 \%$ in 2016.In the same period, excise revenue -GDP ratio decreased in Ireland from $4.1 \%$ to 2.1 \%, Norway from $3.6 \%$ to $2.6 \%$, Denmark from $5.2 \%$ to $4 \%$, Sweden from $3 \%$ to $2.2 \%$, UK from $3.4 \%$ to $2.5 \%$. On the other hand, for 2000-2016 period, share of excise revenues in GDP revenue have increased in Turkey from 2,8 \% to 4,6 \%, Slovenia from 3,1 \% to 4,2 \%, Italy from 2,5\% to 2,9 \%, Israel from 1,2 \% to 1,5 \%, Estonia from $3 \%$ to 4,8 \% and Czech Republic from $3 \%$ to 3,3 \%.

\section{Graph 3: Excise Revenue as percentage of GDP in Developed Countries and Turkey}

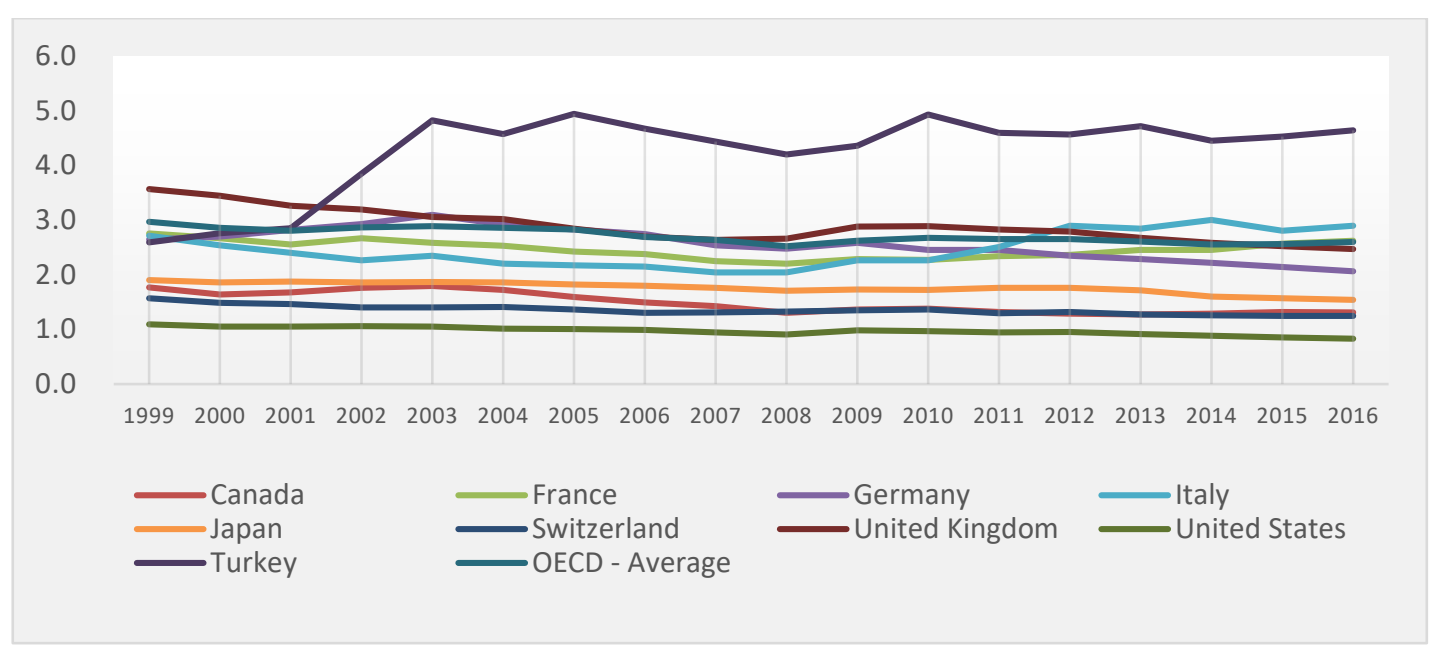

Source: Revenue Statistics - OECD countries

Therewithal, OECD average of excise tax revenues share in total tax revenues has decreased from 9 \% to 7,7 \% in 2000-2016 period. Despite reduction in most OECD members, share of excise revenue in total tax revenue increased in Czech Republic, Estonia, Israel, Italy, Slovenia and Turkey. 
Additionally, Turkey has the highest rate among OECD countries, with a rate of $18.2 \%$. Estonia and Slovenia follow Turkey with $13.6 \%$ and $11.4 \%$ respectively. The United States is the country with the lowest rate of $3.2 \%$.

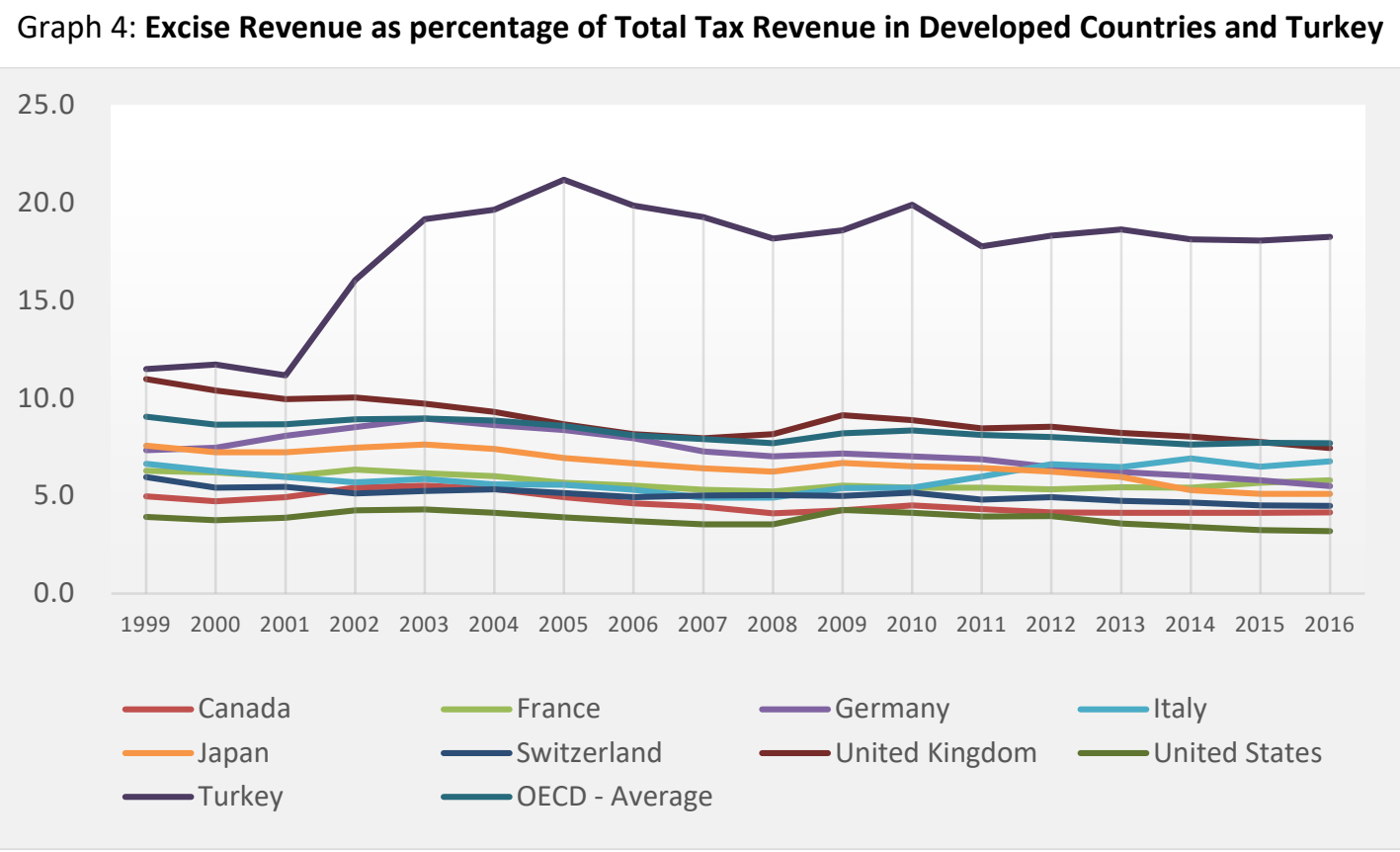

Source: Revenue Statistics - OECD countries

Table 1: Excise Revenue and Total Tax Revenue as percentage of GDP in G7 Countries and Turkey

\begin{tabular}{r|ccc}
\hline \multicolumn{2}{c}{ Excise as \% of GDP } & Excise as \% of Total Tax & Total Tax as \% of GDP \\
\hline Canada & 1,3 & 4,2 & 31,7 \\
France & 2,6 & 5,8 & 45,3 \\
Germany & 2,1 & 5,5 & 37,6 \\
Italy & 2,9 & 6,8 & 42,9 \\
Japan & 1,5 &.. &.. \\
United & 2,5 & 7,4 & 33,2 \\
Kingdom & & & 26,0 \\
United States & 0,8 & 3,2 & 25,5 \\
Turkey & 4,6 & 18,2 & 34,3 \\
OECD - & 2,6 & 7,7 & \\
Average & & &
\end{tabular}

Source: Revenue Statistics - OECD countries

\section{Budget Deficit}

Sustainability of budget deficits is defined as managing financial resources to meet current and future expenditure obligations of government (Haris, 2000:1-24). The fact that the rate of increase in tax revenues is low, compared to the increase in public expenditures due to the political preferences and policies pursued in many developing countries causes the budget deficits and public debt stocks to increase. Moreover, the frequent external debt crises and insufficiency of 
domestic savings in these countries are forcing governments to focus on internal resources in the financing of budget deficits. There are different opinions in the theoretical literature about the importance of budget deficits. In the pre-Keynesian classical approach, the budget should be balanced, and the commitment to the equivalent budget is clearly favored by both politicians and governments throughout the Great Recession period. Unlike the classical ones, Keynes considers budget deficits and fiscal policies as elements of total demand (Corsetti and Roubini, 1997:27-54).

Thus, Keynes states that there is no need to balance the budget deficits in recession and revival periods and advocates the cyclical budget balance. In addition, Keynes considered budget deficits as a clear indicator of the effect of fiscal policy on total demand and has developed the concept of structural budget deficit. Keynes supposed that budget deficit as an endogenous indicator because it can be affected by the economic situation (Blanchard and Fischer, 1989).

On the other hand, Keynesian opinion argued that in an economy fallen behind full employment, budget deficits should not be considered as a sign of debt or debt increase from taxpayers in the future, and that the current consumption of individuals who cannot perceive the burden of borrowing can increase and encourages investments. Thus, the economy will have a higher growth trend with budget deficits and tax revenues will be increased. As a result, budget deficits are important, and their effect varies depending on the circumstances in which they occur (Abizadeh and Yousefi, 1999:118-130).

If government policy is subject to a temporal budget limit, large budget deficits are eventually followed by higher taxes or lower expenditures. The question of which government should choose these two methods to cut major budget deficits has recently gained considerable political and academic interest. For future thinkers, the question of which method to choose is important for calculating optimal consumption plans and for many other private sector decisions (Bohn, 1991:333-359).

Given the fact that public expenditures are financed mainly by taxes, the question of whether taxes affect public expenditures or public spending affects taxes is important for examining whether budget deficits can be taken under control or not (Shah and Buffers, 1994: 311-331).

Although there is complete consensus on the need to reduce budget deficits, it cannot be said that there is the same consensus on ways to reduce these deficits. As a solution to reduce budget deficits, reducing public spending and increasing taxes are still being discussed. In the literature, the relationship between taxes and expenditures there are four alternative theories of public finance.

1. Institutional Separation Theory: The institutional separation theory expressed by Baghestani and McNown relates to the institutional separation of government taxation and spending decisions. This perspective shows that revenues and expenditures are independent of each other (Payne and Ewing, 1998:57-69).

2. Tax Expenditure Theory: Milton Friedman is one of the greatest advocates of the taxexpenditure theory that the rise in revenues will lead to increases in public spending. Friedman (1978) argues that there is a causal relationship between taxes and expenditures, and tax increases lead to an increase in public spending. Increasing taxes will mean that the same budget deficit will be at a higher expenditure level (Anderson, 1985:467-469).

3. Spending Tax Theory: Theory expresses that change in public expenditures cause a change in public revenues. Peacock and Wiseman begin the analysis with the assumption that the level of taxation is a limitation of the increase in expenditures and suggests the idea of a tolerable 
level of taxation. The periods of severe crises wars, natural disasters, heavy stagnation, etc. caused by the extraordinary nature of these situations require a surplus of spending and shift the level of bearable taxation upward. As soon as the crisis is over, public spending returns to normal, but returns to normal at a higher level than pre-crisis spending. Because, society gets used to the level of new taxation. Thus, the public sector will displace the private sector with increasing taxation and expenditure (Quintieri and Bella, 1997:214-234).

4. Financial Synchronization Theory: According to this theory, the state compares the benefits and costs of public expenditures and simultaneously determines the amounts of public expenditures and tax revenues. There is a mutual causal relationship between these two variables, as public administrators are in an effort to support a constant harmony between tax revenues and public expenditures (Terzi and Oltulular, 2006:4).

\subsection{Budget Deficit in OECD and Turkey}

To force countries to reduce their debts, the Maastricht Treaty, which entered into force in 1993, made some arrangements. To enable the member states of the European Union to take part in the Economic and Monetary Union; It is stated that annual budget deficits should not exceed 3\% of GDP and total debt stock should not exceed $60 \%$ of their GDP. Many countries, particularly the United States (USA), have followed expansionary monetary and fiscal policies to end the effects of the 2008 global economic crisis. This situation has deteriorated the budget balances of the countries concerned.

As shown in Table 2, the main countries with a high rate of annual GDP deficits in 2017 are the United States, South Africa, Spain, Portugal, France, Italy, Hungary, United Kingdom, and Turkey. The countries that are above the threshold specified in the Maastricht Criteria (3\%) are United States, South Africa, Spain, and Portugal. In these countries, the sustainability of budget deficits is at risk. However, this situation is quite good compared to the crisis and after crisis period. According to IMF data; In 2011, 141 out of 184 countries in the world experienced a budget deficit.

Turkey's economy has created an economic structure in the spiral the crisis-growth as the result of the structural instability depending on the high level of debt due to public deficits and high chronic inflation from the mid-1980s until the 2000s. Public finance, financial system resulting from this situation, weak and fragile structure in the real economy increased the possibility of crisis (Karaçor, 2006). It was decided to switch to the inflation reduction program covering the period of 2000-2002. The program was successfully implemented with the support and confidence of the public until November 2000, but the developments in the banking sector increased the question marks in the economy (Günal, 2007). As risk, uncertainty, insecurity, non-transparent financial markets and inflation expectations are added to this process, the possibility of a new crisis has increased. The crisis became inevitable with the problems in implementation of effective policy and the November 2000 crisis was experienced (Karaçor, 2006). 
Table 2: General Government Deficit as percentage of GDP in OECD Countries

\begin{tabular}{|c|c|c|c|c|c|c|c|c|c|c|}
\hline Country & 2008 & 2009 & 2010 & 2011 & 2012 & 2013 & 2014 & 2015 & 2016 & 2017 \\
\hline United States & $-7,4$ & $-13,1$ & $-12,4$ & $-11,0$ & $-9,2$ & $-5,8$ & $-5,2$ & $-4,6$ & $-5,3$ & $-4,1$ \\
\hline South Africa & $-1,7$ & $-3,9$ & $-3,3$ & $-2,5$ & $-3,6$ & $-3,6$ & $-3,8$ & $-3,8$ & $-3,5$ & $-4,0$ \\
\hline Spain & $-4,4$ & $-11,0$ & $-9,4$ & $-9,6$ & $-10,5$ & $-7,0$ & $-6,0$ & $-5,3$ & $-4,5$ & $-3,1$ \\
\hline Portugal & $-3,8$ & $-9,8$ & $-11,2$ & $-7,4$ & $-5,7$ & $-4,8$ & $-7,2$ & $-4,4$ & $-2,0$ & $-3,0$ \\
\hline France & $-3,3$ & $-7,2$ & $-6,9$ & $-5,2$ & $-5,0$ & $-4,1$ & $-3,9$ & $-3,6$ & $-3,5$ & $-2,7$ \\
\hline Italy & $-2,6$ & $-5,2$ & $-4,2$ & $-3,7$ & $-2,9$ & $-2,9$ & $-3,0$ & $-2,6$ & $-2,5$ & $-2,4$ \\
\hline Hungary & $-3,7$ & $-4,5$ & $-4,5$ & $-5,4$ & $-2,4$ & $-2,6$ & $-2,6$ & $-1,9$ & $-1,6$ & $-2,2$ \\
\hline United Kingdom & $-5,2$ & $-10,1$ & $-9,3$ & $-7,5$ & $-8,1$ & $-5,4$ & $-5,4$ & $-4,2$ & $-2,9$ & $-1,8$ \\
\hline Turkey & $-1,8$ & $-5,3$ & $-3,5$ & $-1,3$ & $-1,9$ & $-1,0$ & $-1,1$ & $-1,0$ & $-1,1$ & $-1,5$ \\
\hline Poland & $-3,6$ & $-7,3$ & $-7,3$ & $-4,8$ & $-3,7$ & $-4,1$ & $-3,7$ & $-2,7$ & $-2,2$ & $-1,4$ \\
\hline Canada & 0,2 & $-3,9$ & $-4,7$ & $-3,3$ & $-2,5$ & $-1,9$ & 0,2 & $-0,1$ & $-1,1$ & $-1,1$ \\
\hline$E U$ & $-2,5$ & $-6,6$ & $-6,4$ & $-4,6$ & $-4,3$ & $-3,3$ & $-2,9$ & $-2,3$ & $-1,7$ & $-1,0$ \\
\hline Israel & $-3,6$ & $-6,5$ & $-3,7$ & $-3,0$ & $-4,4$ & $-4,0$ & $-2,4$ & $-1,0$ & $-1,4$ & $-1,0$ \\
\hline Belgium & $-1,1$ & $-5,4$ & $-4,0$ & $-4,2$ & $-4,2$ & $-3,1$ & $-3,1$ & $-2,5$ & $-2,4$ & $-0,9$ \\
\hline Austria & $-1,5$ & $-5,3$ & $-4,4$ & $-2,6$ & $-2,2$ & $-2,0$ & $-2,7$ & $-1,0$ & $-1,6$ & $-0,8$ \\
\hline Slovak Republic & $-2,4$ & $-7,8$ & $-7,5$ & $-4,3$ & $-4,3$ & $-2,7$ & $-2,7$ & $-2,6$ & $-2,2$ & $-0,8$ \\
\hline Finland & 4,2 & $-2,5$ & $-2,6$ & $-1,0$ & $-2,2$ & $-2,6$ & $-3,2$ & $-2,8$ & $-1,7$ & $-0,7$ \\
\hline Latvia & $-4,2$ & $-9,1$ & $-8,7$ & $-4,3$ & $-1,2$ & $-1,2$ & $-1,5$ & $-1,4$ & 0,1 & $-0,6$ \\
\hline Estonia & $-2,7$ & $-2,2$ & 0,2 & 1,2 & $-0,3$ & $-0,2$ & 0,7 & 0,1 & $-0,3$ & $-0,4$ \\
\hline Ireland & $-7,0$ & $-13,8$ & $-32,0$ & $-12,8$ & $-8,1$ & $-6,1$ & $-3,6$ & $-1,9$ & $-0,5$ & $-0,2$ \\
\hline Iceland & $-12,9$ & $-9,5$ & $-9,5$ & $-5,4$ & $-3,6$ & $-1,8$ & $-0,1$ & $-0,8$ & 12,3 & 0,0 \\
\hline Slovenia & $-1,4$ & $-5,8$ & $-5,6$ & $-6,7$ & $-4,0$ & $-14,7$ & $-5,5$ & $-2,8$ & $-1,9$ & 0,1 \\
\hline Lithuania & $-3,1$ & $-9,1$ & $-6,9$ & $-8,9$ & $-3,1$ & $-2,6$ & $-0,6$ & $-0,3$ & 0,3 & 0,5 \\
\hline Greece & $-10,2$ & $-15,1$ & $-11,2$ & $-10,3$ & $-8,9$ & $-13,2$ & $-3,6$ & $-5,6$ & 0,5 & 0,8 \\
\hline Germany & $-0,2$ & $-3,2$ & $-4,2$ & $-1,0$ & 0,0 & $-0,1$ & 0,6 & 0,8 & 0,9 & 1,0 \\
\hline Denmark & 3,2 & $-2,8$ & $-2,7$ & $-2,1$ & $-3,5$ & $-1,2$ & 1,1 & $-1,5$ & $-0,4$ & 1,1 \\
\hline Netherlands & 0,2 & $-5,1$ & $-5,2$ & $-4,4$ & $-3,9$ & $-2,9$ & $-2,2$ & $-2,0$ & 0,0 & 1,2 \\
\hline Switzerland & 1,9 & 0,5 & 0,4 & 0,7 & 0,4 & $-0,4$ & $-0,2$ & 0,6 & 0,4 & 1,3 \\
\hline Luxembourg & 3,3 & $-0,7$ & $-0,7$ & 0,5 & 0,3 & 1,0 & 1,3 & 1,3 & 1,6 & 1,4 \\
\hline Czech Republic & $-2,0$ & $-5,5$ & $-4,2$ & $-2,7$ & $-3,9$ & $-1,2$ & $-2,1$ & $-0,6$ & 0,7 & 1,5 \\
\hline Sweden & 1,9 & $-0,7$ & 0,0 & $-0,2$ & $-1,0$ & $-1,4$ & $-1,6$ & 0,2 & 1,1 & 1,6 \\
\hline Korea & 2,3 & $-1,3$ & 1,0 & 1,0 & 1,0 & 1,3 & 1,3 & 1,3 & 2,4 & 2,8 \\
\hline Norway & 18,7 & 10,3 & 11,0 & 13,4 & 13,8 & 10,8 & 8,7 & 6,1 & 4,0 & 5,1 \\
\hline
\end{tabular}

Source: General Government Deficit (Indicator), OECD

The regulations to prevent the collapse of the banking system following the crisis led state financial obligations to very high levels. Capital account in balance of payments large net output has occurred. 
The real economy contracted significantly due to the negative effects of supply and demand. The view that the exit from the crisis cannot be fast and easy became widespread (Celasun, 2002: 17).

\section{Graph 5: General Government Deficit as \% of GDP in G7 and Turkey}

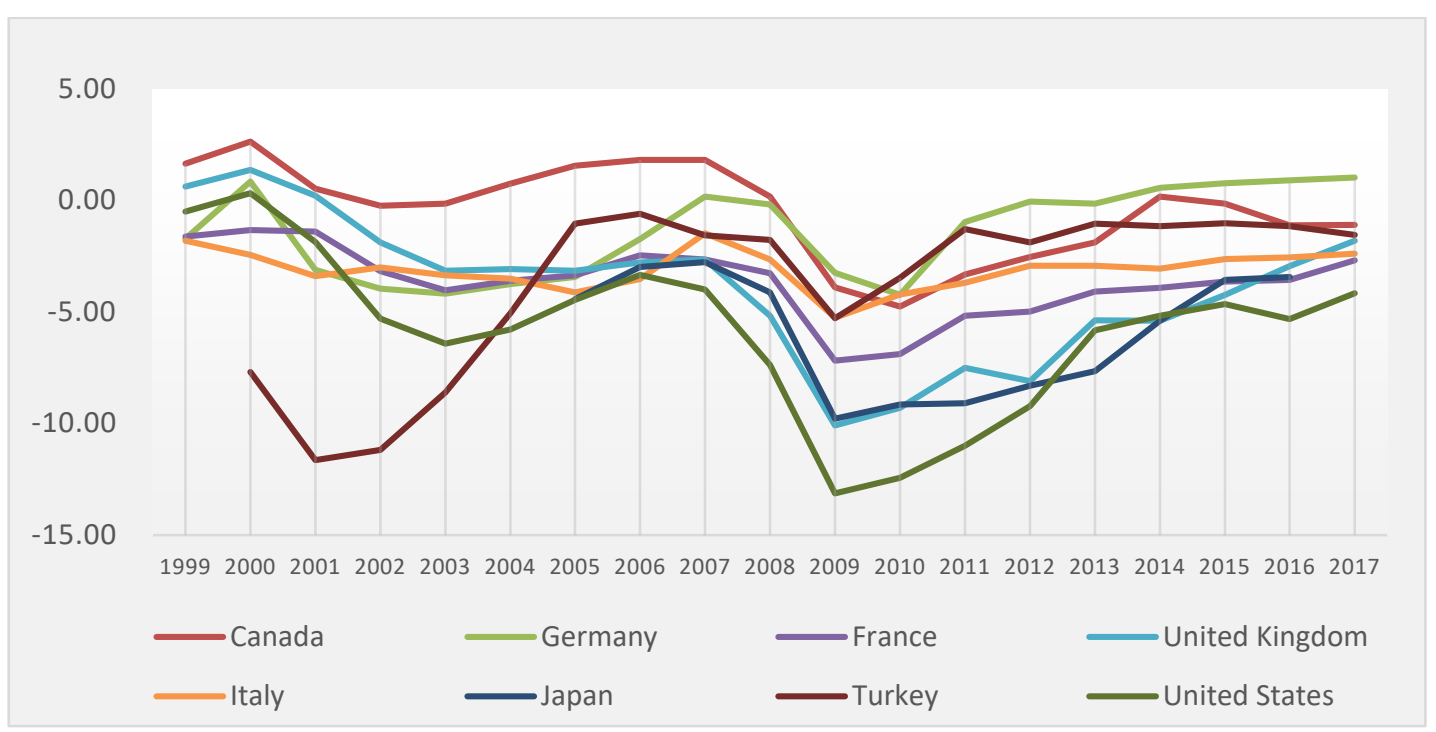

Source: General Government Deficit (Indicator), OECD

After the crises, primary surplus policies that contribute to the formation of a sustainable growth, support the fight against inflation and attract public debt stock to reasonable levels have continued. As a natural requirement of the tight fiscal policy implemented, precautions to increase income and disciplinary measures were taken, and fiscal adjustment was achieved with incomeincreasing policies. High rate of growth also contributed to this process by increasing revenues (Dokuzuncu Kalkınma Planı 2007 - 2013, 2006: 13).

The Turkish economy has achieved a stable process due to the mentioned reforms. However, there has been an economic crisis and instability which started in the last quarter of 2007 and stemmed from high-risk housing loans in the US economy, reflected in the financial markets and institutions in Europe (particularly in the UK), Canada and Japan (Batırel, 2008:2).

Turkey's economy with the resulting contraction in the global economy has also been affected by this volatility tends to slow down. Negative impacts on public expenditure and income balances have appeared due to the crisis. However, again to ensure fiscal discipline in the medium term, was among the main priorities of Turkey's economy (Taban, 2011:16). 
Graph 6: Central Government Budget and Budget Deficit in Turkey

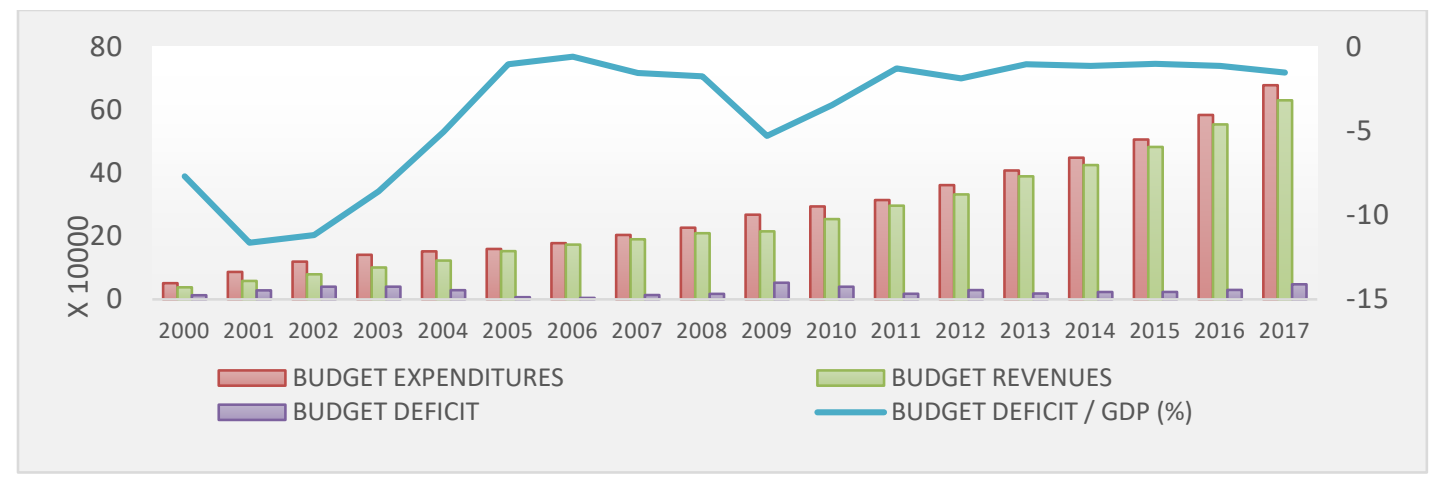

Source: Basic Economic Indicators, General Directorate of Budget and Fiscal Control

\section{Data and Methodology}

The analysis includes the bootstrap panel Granger causality proposed by Kónya (2006) and performs a panel with 32 cross-sections (32 OECD member countries, Chile, Japan, Lithuania and Mexico are not included due to lack of data) and 18 years (the period 1999-2016). Kónya's (2006) proposal does not require unit root and co-integration tests for variables. Thus, variables are used at their own level. Additionally, this tool considers the existence of contemporary correlations between countries and supplies more panel information (equations create a SUR system) and the procedure needs one-way, two-way or Granger causality between variables for each country.

In the study, Excise Tax Revenue as \% of GDP has been used as excise tax data and General Government Deficit as \% of GDP has been used as deficit data. Data are obtained annually from the OECD database.

The bootstrap panel Granger causality test proposed by Kónya (2006) considers two main assumptions: cross-sectional dependency and cross-country heterogeneity.

\subsection{Cross-Sectional Dependence}

A possible cross-sectional dependency problem in a panel analysis often results in inconsistent and upward prediction results (Bai and Kao, 2006:3-30). Therefore, it should be tested before analysis. In this study, Pesaran (2004) method was used to investigate the presence of crosssectional dependence. Pesaran (2004), suggests a test for cross-sectional dependence (CD) that can be applied where $\mathrm{N}$ is large, and $\mathrm{T}$ is small.

The CD statistic is calculated as follows:

$C D=\sqrt{\frac{2 T}{N(N-1)}}\left(\sum_{i=1}^{N-1} \sum_{J=i+1}^{N}\left(\hat{\rho}_{i j}\right)\right.$

According to Pesaran (2004), under the null hypothesis of no cross-sectional dependence with $\mathrm{T} \rightarrow \infty$ and $\mathrm{N} \rightarrow \infty$ in any order, the CD test is asymptotically normally distributed.

In the equation, $\mathrm{N}$ is the number of countries, $\mathrm{T}$ is the period, and $\rho_{i j}$ is the sample estimation of the double correlation of the error terms. 


\subsection{Slope Homogeneity Tests}

The cross-country heterogeneity is tested by the standardized version of Swamy's (1970) test for slope homogeneity proposed by Pesaran and Yamagata (2008) and its improved version.

Pesaran and Yamagata (2008) argue that both the F-test and the Swamy test need panel data models where $\mathrm{N}$ is relatively small compared to $\mathrm{T}$. For this reason, they suggest a standardized version of Swamy's test ( $\tilde{\Delta}$ test) for testing slope homogeneity in large panels. The $\Delta$ test is effective where $(\mathrm{N}, \mathrm{T}) \rightarrow \infty$ without any restrictions on the relative expansion rates of $\mathrm{N}$ and $\mathrm{T}$.

Swamy's statistic can then be varied as:

$\widetilde{S}=\sum_{i=1}^{N}\left(\widehat{\beta}_{i}-\hat{\beta} w f e\right)^{\prime} \frac{X_{i}^{\prime} M \tau X_{i}}{\widehat{\sigma}_{i}^{2}}\left(\widehat{\beta}_{i}-\widehat{\beta} w f e\right)$

where $\widehat{\beta}_{\mathrm{i}}$ is the pooled OLS estimator; $\widehat{\beta}$ wfe is the weighted fixed effect pooled estimator of the Equation 1; M $\tau$ is an identity matrix of order $\mathrm{T}$ and $\widehat{\sigma}_{\mathrm{i}}^{2}$ is the estimator of $\sigma_{\mathrm{i}}^{2}$.

Pesaran and Yamagata (2008) then developed the standardized distribution statistic:

$\tilde{\Delta}=\sqrt{N}\left(\frac{N^{-1} \tilde{S}-k}{\sqrt{2 k}}\right)$

The $\tilde{\Delta}$ test when the error terms are normally distributed has an asymptotic standard normal distribution under the null hypothesis with the condition of $(N, T) \rightarrow \infty$ and so long as $V N / T \rightarrow \infty$.

\subsection{Panel Causality Test}

The panel causality technique proposed by Kónya (2006) requests defining a system which includes two sets of equations.

This approach can be formulated as follows:

$$
\begin{aligned}
& E T_{1, t}=\alpha_{1,1}+\sum_{i=1}^{k y} \beta_{1,1, i} E T_{1, t-i}+\sum_{i=1}^{k e} \delta_{1,1, i} B D_{1, t-i}+\varepsilon_{1,1, t} \\
& E T_{2, t}=\alpha_{1,2}+\sum_{i=1}^{k y} \beta_{1,2, i} E T_{2, t-i}+\sum_{i=1}^{k e} \delta_{1,2, i} B D_{2, t-i}+\varepsilon_{1,2, t} \\
& E T_{N, t}=\alpha_{1, N}+\sum_{i=1}^{k y} \beta_{1, N, i} E T_{N, t-i}+\sum_{i=1}^{k e} \delta_{1, N, i} B D_{N, t-i}+\varepsilon_{1, N, t}
\end{aligned}
$$


$\&$

$$
\begin{aligned}
& B D_{1, t}=\alpha_{2,1}+\sum_{i=1}^{k y} \beta_{2,1, i} E T_{1, t-i}+\sum_{i=1}^{k e} \delta_{2,1, i} B D_{1, t-i}+\varepsilon_{2,1, t} \\
& B D_{2, t}=\alpha_{2,2}+\sum_{i=1}^{k y} \beta_{2,2, i} E T_{2, t-i}+\sum_{i=1}^{k e} \delta_{2,2, i} B D_{2, t-i}+\varepsilon_{2,2, t} \\
& B D_{N, t}=\alpha_{2, N}+\sum_{i=1}^{k y} \beta_{2, N, i} E T_{N, t-i}+\sum_{i=1}^{k e} \delta_{2, N, i} B D_{N, t-i}+\varepsilon_{2, N, t}
\end{aligned}
$$

where ET and BD denote excise tax revenue as \% of GDP, and general budget deficit as \% of GDP, respectively. $N$ is the number of countries of the panel $(i=1,2,3, N), t$ is the time period $(t=1,2$, $3, \ldots, \mathrm{T})$, and "I" is the lag length. The error terms, $\varepsilon_{1, N, t}$ and $\varepsilon_{2, N, t}$, are supposed to be white noise and may be correlated with each other for a given country.

By testing the Granger causality in this system, it is possible to have different causal relationships for a country. For example, there is one-way Granger causality from BD to ET if not all $\delta_{1, i}$ are zero, but all $\beta_{2, i}$ are zero; there is one-way Granger causality from ET to BD if all $\delta_{1, i}$ are zero, but not all $\beta_{2, i}$ are zero; there is two-way Granger causality between ET and BT if neither $\delta_{1, i}$ nor $\beta_{2, i}$ is zero; there is no Granger causality between $\mathrm{ET}$ and BD if all $\delta_{1, i}$ and $\beta_{2, i}$ are zero.

\subsection{Empirical Findings}

In this section, the empirical results are reported. Cross-sectional dependency and slope homogeneity among the countries were tested before panel causality analysis. The results are shown in Table 3.

Table 3: Cross-Sectional Dependency and Slope Homogeneity Tests

\begin{tabular}{lcc}
\hline Cross-section dependency test & Statistic & p-Value \\
\hline CD (Pesaran, 2004) & $20.226^{*}$ & 0.000 \\
& & p-Value \\
\hline Slope homogeneity tests & Statistic & 0.000 \\
Delta & $6.201^{*}$ & 0.000 \\
Delta Adj & $6.793^{*}$ & \\
\end{tabular}

Note: $(*)$ shows rejection of the null hypothesis at the $1 \%$ level of significance.

The results in Table 3, show that the null hypothesis of no cross-sectional dependence across the countries is strongly rejected at the $1 \%$ level of significance. This result says that a change, which may occur in one of the selected OECD countries, seems to influence other countries, because of their integrated economies. Findings in Table 4 also reveal result of slope homogeneity tests that 
show that the null hypothesis of the slope homogeneity is rejected. This result shows that the direction of panel causality analysis between variables in 32 OECD countries might be heterogeneous and the direction of causal relationships among the variables may differ across countries.

The existence of cross-sectional dependence and heterogeneity among selected OECD countries means that it is suitable to use the Bootstrap panel Granger causality method by Kónya (2006).

The causality test results of excise tax revenue and budget deficit in Table 4 show that for Australia, Belgium, Canada, Denmark, Finland, France, Germany, Greece, Israel, Italy, Korea ,Latvia, Luxembourg ,New Zealand, Norway, Poland, Slovenia, Spain, Sweden, Switzerland, and Turkey there is a significant (at the $10 \%$ level of significance) bidirectional causality between excise tax revenue and budget deficit. On the other hand, there is a significant causality (at the $10 \%$ level of significance) from excise tax revenue to budget deficit for Slovak Republic, United Kingdom, and United States. In addition, significant causality (at the $10 \%$ level of significance) from budget deficit to excise tax revenue exists for Austria, Czech Republic, Estonia, Hungary, Iceland, and Ireland.

Table 4: Test Results of Causality from Excise Tax Revenue to Budget Deficit

\begin{tabular}{|c|c|c|}
\hline & $\begin{array}{c}\text { HO: EX does not Granger } \\
\text { causes BD }\end{array}$ & $\begin{array}{c}\text { HO: BD does not Granger } \\
\text { causes EX }\end{array}$ \\
\hline Country & Wald Test-stat. & Wald Test-stat. \\
\hline Australia & $11,25 * * *$ & $5,14 * *$ \\
\hline Austria & 1,04 & $4289,07 * * *$ \\
\hline Belgium & $39,02 * * *$ & $304,50 * * *$ \\
\hline Canada & $15,60 * * *$ & $7,32 * * *$ \\
\hline Czech Republic & 1,6 & $2,75 *$ \\
\hline Denmark & $26,93 * * *$ & $181,63 * * *$ \\
\hline Estonia & 2,41 & $183,95 * * *$ \\
\hline Finland & $77,32 * * *$ & $7976,56 * * *$ \\
\hline France & $29,86 * * *$ & $129,37 * * *$ \\
\hline Germany & $50,84 * * *$ & $1638,06 * * *$ \\
\hline Greece & $28,82 * * *$ & $12154,83 * * *$ \\
\hline Hungary & 0,49 & $186,82 * * *$ \\
\hline Iceland & 0,44 & $6452,65 * * *$ \\
\hline Ireland & 2 & $59,28 * * *$ \\
\hline Israel & $4,77 * *$ & $787,96 * * *$ \\
\hline Italy & $26,36 * * *$ & $22,41 * * *$ \\
\hline Korea & $3,43 *$ & $7,50 * * *$ \\
\hline Latvia & $64,09 * * *$ & $7,02 * * *$ \\
\hline Luxembourg & $3,21 *$ & 3,16 * \\
\hline Netherlands & 0,74 & 1,65 \\
\hline
\end{tabular}




\begin{tabular}{|lll|} 
New Zealand & $47,89^{* * *}$ & $7,10^{* * *}$ \\
Norway & $22,40^{* * *}$ & $32,50^{* * *}$ \\
Poland & $5,92^{* *}$ & $51,11^{* * *}$ \\
Portugal & 1,8 & 0,22 \\
Slovak Republic & $6,45^{* *}$ & 0,94 \\
Slovenia & $4,66^{* *}$ & $55,53 * * *$ \\
Spain & $14,63^{* * *}$ & $16,19^{* * *}$ \\
Sweden & $3,43^{*}$ & $13,84^{* * *}$ \\
Switzerland & $5,72^{* *}$ & $19,60^{* * *}$ \\
Turkey & $68,77^{* * *}$ & $19,07^{* * *}$ \\
United Kingdom & $12,50^{* * *}$ & 0,46 \\
United States & $3,92^{* *}$ & 0,62 \\
\hline
\end{tabular}

Note: ${ }^{* * *}, * *$ and $*$ denote the significance for at $0.1,0.05$ and 0.01 levels.

Overall, in this analysis strong evidence of causality between excise tax revenue and budget deficit has been found for all the selected OECD countries, except Portugal and Netherland. Table 5 summarizes the direction of Granger causality analysis of excise tax revenue and budget deficit for all selected OECD countries.

Table 5: Direction of Granger Causality Relationship between Countries

\begin{tabular}{c|c}
\hline Direction of Granger Causality & Country \\
\hline E<-->D & $\begin{array}{r}\text { Australia, Germany, Luxembourg, Sweden, Belgium, } \\
\text { Greece, New Zealand, Switzerland, Canada, } \\
\text { Israel, Norway, Turkey, Denmark, Italy, Poland, } \\
\text { Finland, Korea, Slovenia, France, Latvia, Spain. }\end{array}$ \\
\hline E-->D & Slovak Republic, United Kingdom, United States. \\
\hline N-->E & Austria, Czech Republic, Estonia, Hungary. \\
\hline None & Netherlands, Portugal. \\
\hline
\end{tabular}

Note: E, D denote excise tax revenue and budget deficit respectively. "-->" stands for direction of causality.

\section{Conclusion}

A budget deficit has been seen in the economies of OECD member countries for many years. In this study, the relationship between the budget deficits and excise tax revenues of the OECD countries is examined with the annual data of 1999-2016 period. To do this, the bootstrap panel causality technique proposed by Kónya (2006), which considers cross-sectional dependence and heterogeneity across the countries, was employed. In the analysis, Excise Tax Revenue as percentage of GDP has been used as excise tax data and General Government Deficit as percentage of GDP has been used as deficit data. 
The empirical findings show strong evidence of causality between excise tax revenue and budget deficit. To note that, only in Portugal and Netherland, no strong evidence of causality was found. For the rest of the countries considered in this study, significant relationship between excise tax revenue and budget deficit was detected.

Using excise taxes to remedy the budget deficit can be a politically better solution than using institutions and individual taxes. In general, the fact that it is applied to activities that are harmful to health or the environment has an effect that decreases the social reaction in increasing these taxes. However, there are doubts about the sustainability of excise tax revenues. Excise taxes serve to increase both revenues and reduce consumption of taxable activity. Thus, it is difficult to estimate the excise taxes due to this dual function. When the government increases the excise tax on cigarettes, it will cause a decrease in consumption due to higher sales price. For example, Lewit and Coate (1982) found that young smokers were more sensitive than elderly smokers and that price increases were considered in cigarette consumption decisions. Therefore, the decrease in the number of smokers will cause a decrease in the tax base of the state. On the other hand, there are studies showing that consumption is not much affected by taxation. For example, Callison and Kaestner (2014) suggest that adult smoking is unaffected by taxes in their analysis of the association between cigarette taxes and adult cigarette use.

Despite these sustainability concerns, considering the results of the analysis, the advantages of special consumption taxes for governments are more prominent and it can be concluded that governments prefer excise tax revenues to keep budget deficits under control.

\section{References}

Abizadeh, S., Benarroch, M., and Yousefi, M. (1996). A Multilevel Government Model of Deficits and Inflation. Atlantic Economic Journal, 24(2), 118-130.

Altinok, S. (2007). Avrupa Birliği ile İlişsiler Çerçevesinde Özel Tüketim Vergisi Uygulaması ve Türkiye Örneği (Unpublished Master Thesis). Süleyman Demirel Üniversitesi, Isparta.

Anderson, L. (1961). The Southwestern Social Science Quarterly, 41(4), 467-469. Retrieved from http://www.jstor.org/stable/42866601

Baia, J. and Kaob, C. (2006). On the estimation and inference of a panel cointegration model with crosssectional dependence. In Panel Data Econometrics Theoretical Contributions and Empirical Applications (pp. 3-30). Emerald Group Publishing Limited.

Batırel, Ö. F. (2008). Global Ekonomik Kriz ve Türk Kamu Maliyesi. İstanbul Ticaret Üniversitesi Sosyal Bilimler Dergisi, 7(13), 1-9.

Bird, R. M. (2015). Tobacco and Alcohol Excise Taxes for Improving Public Health and Revenue Outcomes :Marrying Sin and Virtue ? (English). Policy Research Working Paper; No. WPS 7500, Washington, D.C.: World Bank Group

Blanchard, O.J. and Fischer S. (1989). Lectures on Macroeconomics. Cambridge: The MIT Press.

Bohn, H. (1991). Budget Balance through Revenue or Spending Adjustments? Journal of Monetary Economics, 27, 333-359.

Brezis, M. and Marans, R. (2010). Do People Support Sin Taxes? A Population Survey of Attitudes. World Medical and Health Policy, 2 (4), Article 4. 
Buchanan, J. M. (1970). Political Economy and National Priorities: A Review Essay of the Economic Report of the President and the Annual Report of the Council of Economic Advisers. Journal of Money, Credit and Banking, 2(4), 486-492.

Callison, K. and Kaestner, R. (2014). Do higher tobacco taxes reduce adult smoking? New evidence of the effect of recent cigarette tax increases on adult smoking. Economic Inquiry, 52(1), 155172.

Celasun, M. (2002). 2001 Krizi, Öncesi ve Sonrası: Makroekonomik ve Mali Bir Değerlendirme. 7. Ulusal Sosyal Bilimler Kongresi: Küreselleşme, Emek Süreçleri ve Yapısal Uyum, 27-102, Ankara

Cooper, A. and Witt, D. (2012). The Linkage between Tax Burden and Illicit Trade of Excisable Products: The Example of Tobacco. World Customs Journal, 6(2), 41-58.

Corsetti, C. and Roubini N. (1997). Politically Motivated Fiscal Deficit: Policy Issues in Closed and Open Economy. Economic and Politics, 9(1), 27-54.

Crooks, E. (1989). Alcohol Consumption and Taxation, London: Institute for Fiscal Studies.

Dokuzuncu Kalkınma Planı 2007 - 2013. (2006). Retrieved from https://pbk.tbmm.gov.tr/dokumanlar/kalkinma-plani-9-genel-kurul.pdf

Edizdoğan, N. and Çelikkaya, A. (2010). Vergilerin ekonomik analizi. Bursa: Dora Yayıncılık.

Eker, A. (1998). Kamu Maliyesi. İzmir: Anadolu Matbaacılık.

Friedman, M. (1978). The Limitations of Tax Limitation. Policy Review, Summer, 7-14.

Günal, M. (2007). Türkiye'de Bankacılık: Sorunlar, Gelişmeler, Çözüm Önerileri. Türkiye Ekonomisi Makroekonomik Sorunlar ve Çözüm Önerileri Edtr. Ahmet Ay. Konya: Çizgi Kitabevi, 319-366.

Haris, J. (2000). Basic Principles of Sustainable Development. Tufts University Global Development and Environment Institute Working Paper, 4,1-24.

Karaçor, Z. (2006). Öğrenen Ekonomi Türkiye: Kasım 2000- Şubat 2001 Krizinin Öğrettikleri. Selçuk Üniversitesi Sosyal Bilimler Enstitüsü Dergisi, 16,379-391.

Kargı, V. and Yüksel, C. (2010). Çevresel Dışsallıklarda Kamu Ekonomisi Çözümleri. Maliye Dergisi, 159, 183-202.

Kónya, L. (2006). Exports and Growth: Granger Causality Analysis on OECD Countries with a Panel Data Approach. Economic Modelling, 23(6), 978-992.

Lewit, E.M. and Coate. D. (1982). The Potential for Using Excise Taxes to Reduce Smoking. Journal of Health Economics, 1(2): 121-145.

Mutlu, A. (2002). Özel Tüketim Vergisi. Yaklaşım Dergisi, 115, 47.

Oecd (2018). General Government Debt (Indicator). Doi: 10.1787/A0528cc2-En (Accessed On 28 November 2018)

Oecd (2018). General Government Deficit (Indicator). Doi: 10.1787/77079edb-En (Accessed On 28 November 2018)

Oecd (2018). General Government Revenue (Indicator). Doi: 10.1787/B68b04ae-En (Accessed On 28 November 2018) 
Payne, E.J. and Ewing, T.B. (1998). Government Revenue-Expenditure Nexus: Evidence from Latin America. Journal of Economic Development, 23/2, 57-69.

Pesaran, M. H. (2004). General Diagnostic Tests for Cross Section Dependence in Panels. IZA Discussion Paper, 1240, Institute of the Study of Labor, Bonn, Germany.

Pesaran, M. H. and Yamagata, T. (2008). Testing Slope Homogeneity in Large Panels.Journal of Econometrics, 142(1), 50-93.

Pigou, A. (2017). The Economics of Welfare. New York: Routledge.

Quintieri, B. and Belle, M. (1997). Causality between Public Expenditure and Taxation, Evidence from the Italian case. Budgetary Policy, Modelling Public Expenditures, London and Newyork, 214234.

Saidi, N. and Prasad, A. (2016). Excise Taxation for Gcc Revenue Diversification, Retrieved From: http://nassersaidi.com/wp-content/uploads/2016/05/Excise-Taxation-for-GCC-RevenueDiversification-Apr-2016-FINAL.pdf

Sassi, F. and Belloni, A. (2014). Fiscal Incentives, Behavior Change and Health Promotion: What Place in The Health-In-All-Policies Toolk It? Health Promotion International, 29103-112.

Shah, A. and Baffers, J. (1994). Causality and Comovement between Taxes and Expenditures: Historical Evidence from Argentina, Brazil and Mexico. Journal of Development Economics, 44, 311-331.

Smith, A. (2006). Milletlerin Zenginliği, İstanbul: Türkiye İş Bankası Kültür Yayınları

Swamy, P. A. V. B. (1970). Efficient Inference in a Random Coefficient Regression Model. Econometrica, 38(2), 311-323.

Taban, S. (2011). Küresel Finans Krizi Öncesi ve Sonrası Dönemde Türkiye'de Ekonomik Büyümenin Dinamikleri. Seta Analiz,37,1-36.

Taylar, Y. (2010). Vergi Teorisi Açısından Özel Tüketim Vergileri ve Türk Özel Tüketim Vergisi Uygulaması. Dokuz Eylül Üniversitesi Hukuk Fakültesi Dergisi, 12,435-467.

Terzi, H. and Oltulular, S. (2006). Harcama-Vergi Geliri Hipotezi: Türkiye Örneği. Atatürk Üniversitesi iktisadi ve Idari Bilimler Fakültesi Dergisi, 20(2), 1-18. Retrieved from http://dergipark.gov.tr/atauniiibd/issue/2690/35367

Tüğen, K. and Güngör, G. (2013). Türkiye'de 1980-2011 Döneminde Bütçe Açıkları ve Açıkların Finansmanında Vergilerin Rolü.Finans Politik and Ekonomik Yorumlar, 50(575),19-30. 